\title{
Kebahagiaan pada Relawan Pelacak Kontak COVID-19
}

\section{Happiness of the COVID-19 Contact Tracking Volunteers}

\author{
Cahyo Harry Sancoko ${ }^{1}$, Rini Sugiarti ${ }^{1}$, Fendy Suhariadi ${ }^{2}$ \\ ${ }^{1}$ Fakultas Psikologi Universitas Semarang, Indonesia \\ ${ }^{2}$ Fakultas Psikologi Universitas Airlangga, Surabaya, Indonesia
}

\begin{abstract}
This study aims to reveal the happiness of the COVID-19 contact tracer volunteers. A qualitative approach with a phenomenological method was employed. Five volunteers were recruited for this study. Data were collected through semistructured interviews and analyzed using an interpretative phenomenological analysis. From the results of the study, it is concluded that the happiness of being a volunteer arises from positive feelings due to perceived benefits they have given to the people in need primarily people who are recovering from COVID-19. Volunteers' happiness also arises from the awareness of their positive life compared to people whose life tests are heavier than they have. The involvement and interaction of volunteers with people who are suffering from COVID-19 makes the volunteers feel more positive and grateful for their life.
\end{abstract}

Keywords: COVID-19 contact tracking, happiness, volunteers

\begin{abstract}
Abstrak: Penelitian ini bertujuan untuk mengetahui kebahagiaan relawan pelacak kontak COVID-19. Penelitian ini menggunakan pendekatan kualitatif dengan metode fenomenologi. Jumlah subjek penelitian ini adalah 5 oang relawan. Pengumpulan data dilakukan melalui wawancara semiterstruktur. Data dianalisis menggunakan interpretative phenomenological analysis. Dari hasil penelitian dapat disimpulkan bahwa kebahagiaan menjadi relawan muncul karena bisa menolong dan merasakan kebahagiaan orang yang sembuh dari COVID-19. Kebahagiaan relawan juga muncul sebagai akibat melihat realita masih banyak orang lain yang ujian hidupnya lebih dari yang dialaminya. Keterlibatan dan interaksi para informan penlitian ini dengan orang yang sedang terkena penyakit COVID-19 telah membuat mereka memandang hidupnya lebih positif dan penuh kesyukuran.
\end{abstract}

Kata Kunci: Kebahagiaan, pelacak kontak COVID-19, relawan

Pendemi Coronavirus Disease 2019 (COVID-19) yang telah melanda dunia telah mengakibatkan begitu banyak korban. Pandemi ini mulai menyerang masyarakat Indonesia mulai awal tahun 2020 (Tuwu,
2020). COVID-19 adalah penyakit menular disebabkan oleh Severe Acute Respiratory Syndrome Coronavirus 2 (SARS-CoV-2). SARS-CoV-2 merupakan coronavirus jenis baru yang belum pernah diidentifikasi sebe-

Korespondensi tentang artikel ini dapat dialamatkan kepada Rini Sugiarti melalui email: rinisugiartipsikologi@usm.ac.id 
lumnya pada manusia. Tanda dan gejala umum infeksi COVID-19 antara lain gejala gangguan pernapasan akut seperti demam, batuk dan sesak napas. Masa inkubasi ratarata 5-6 hari dengan masa inkubasi terpanjang 14 hari. Pada kasus yang berat, COVID-19 dapat menyebabkan pneumonia, sindrom pernapasan akut, gagal ginjal, dan bahkan kematian (Kementerian Kesehatan RI, 2020b).

Dari data tanggal 4 Mei 2021, jumlah kasus konfirmasi positif COVID-19 di Indonesia adalah 1.682.004 jiwa, sembuh sebanyak 1.535.491 jiwa, dan meninggal dunia sebanyak 45.949 jiwa (Nuryanti, 2021). Sementara itu, secara global angka kasus konfirmasi positif COVID-19 per 5 Juni 2021 adalah 173.311.801 jiwa, dengan 156.283.603 orang dinyatakan sembuh dan sebanyak 3.727.177 jiwa meninggal dunia. (Nugrahani, 2021). Angka-angka tersebut menunjukkan begitu besarnya dampak pandemi COVID-19 ini.

Pandemi COVID-19 berdampak pada berbagai bidang kehidupan. Pada bidang pendidikan, pandemi ini telah memaksa berbagai tingkatan lembaga pendidikan yang sebelumnya melaksanakan pembelajaran tatap muka secara langsung kini mengubahnya menjadi secara daring (dalam jaringan). Pendidik yang biasanya mengajar secara konvensional di kelas, tiba-tiba harus mengajar melalui media berbasis internet padahal tingkat literasi media teknologi pada sejumlah pendidik masih belum cukup memadai (Satrianingrum \& Prasetyo, 2021).

Pada aspek ekonomi, pandemi ini menyebabkan banyak tenaga kerja berkurang atau bahkan kehilangan pendapatannya sehingga berpengaruh pada tingkat konsumsi dan daya beli masyarakat terutama mereka yang ada dalam kategori pekerja informal dan pekerja harian. Sebagian besar masyarakat menjadi sangat berhati-hati dalam mengatur pengeluaran keuangannya karena ketidakpastian kapan pandemi ini akan berakhir. Hal ini menyebabkan turunnya daya beli masyarakat akan barang-barang konsumsi dan memberikan tekanan pada sisi produsen dan penjual (Pakpahan, 2020).
Dalam hal interaksi sosial, pandemi COVID-19 secara nyata telah menggeser pola hubungan sosial yang lebih berjarak sebagai upaya untuk mencegah penularan terutama melalui pembatasan jarak sosial dan berbagai perkumpulan sosial hingga penutupan sementara berbagai tempat publik. Perubahan pola hubungan sosial akibat pandemi COVID-19 ini ditengarai berpengaruh pada pola kebudayaan suatu masyarakat, sistem organisasi dan lembaga sosial, dan pola kepeminpinan (Harahap, 2020).

Dampak dari pandemi COVID-19 yang terjadi pada berbagai sektor kehidupan tersebut telah menimbulkan tekanan atau stres pada masyarakat. Muslim (2020) menyatakan bahwa masa pandemi COVID-19 dapat menimbulkan kondisi stres yang meliputi 3 ruang lingkup: stres akademik yang biasa dialami oleh siswa/mahasiswa, stres kerja, dan stres dalam keluarga. Ruang lingkup yang terakhir ini potensial dialami oleh ibu rumah tangga, karena kebijakan WFH (work from home) telah membuat ibu rumah tangga mendadak harus mendampingi putra putrinya belajar di rumah dengan segala persoalannya.

Dalam rangka menangani pandemi COVID-19 ini, berbagai elemen pemerintah dan masyarakat telah bergerak dan saling berkolaborasi. Upaya penanganan yang dilakukan oleh pemerintah dan berbagai organisasi dan kelompok swasta juga telah mengundang partisipasi masyarakat untuk menjadi relawan. Dalam penanganan setiap bencana, baik itu berupa bencana alam ataupun bencana lainnya, sebagian orang muncul menjadi relawan. Hal yang sama terjadi dalam upaya penanganan terhadap pandemi COVID-19 ini. Banyak relawan yang terlibat dalam penanganan COVID19, baik itu merupakan relawan medis ataupun nonmedis. Pada umumnya orang cenderung menghindar dari lingkungan yang rentan untuk terpapar COVID-19, namun justru ada individu-individu yang datang untuk terlibat dalam penanganan dan pengendalian COVID-19 ini sebagai relawan. 
Relawan adalah orang-orang yang tidak memiliki kewajiban menolong suatu pihak tetapi selalu mencari kesempatan untuk bisa membantu orang lain baik secara langsung maupun melalui suatu organsasi tertentu dalam jangka waktu yang relatif lama, memiliki keterlibatan yang cukup tinggi, serta mengorbankan personal costs (misalnya uang, waktu, pikiran) yang dimilikinya (Rizkiawati et al., 2015). Relawan merupakan orang yang dengan sukarela menyediakan waktu dan tenaganya untuk ikut serta dalam melakukan tindakan membantu menangani permasalahan yang ada dalam masyarakat (Raharjo, 2020). Kerelawanan telah menjadi bagian dari pengalaman kemanusiaan. Relawan tidak tergantung dari asal kelompok atau wilayah tertentu karena relawan tidak memperjujuangkan kepentingan kelompok, agama, maupun daerah.

Terdapat beberapa alasan mengapa sesorang memutuskan untuk memilih menjadi relawan. Beberapa hasil penelitian terdahulu menemukan beberapa alasan berikut yang mendorong orang untuk menjadi sukarelawan, yaitu: 1) keinginan untuk menolong sesama dan mempunyai rasa empati (Melina et al., 2012); 2) kecenderungan mementingkan orang lain (Septania, 2020); 3) pandangan hidup untuk bisa bermanfaat tidak hanya pada diri sendiri namun juga bermanfaat bagi orang lain (Fitriani \& Setyawan, 2017).

Menurut Wolf (1990, hlm. 70-71), setidaknya ada sepuluh alasan mengapa orang mau menjadi relawan, yakni: 1) kepuasan diri; 2) altruisme; 3) untuk berkumpul atau bertemu orang; 4) mempelajari sesuatu; 5) mencipta atau mengelola organisasi; 6) mengembangkan kemampuan profesional; 7) untuk memperoleh posisi pemimpin; 8) memperoleh pelatihan atau pengalaman; 9) memasuki organisasi tertentu; dan 10) kepuasan sosial (Raharjo, 2015). Pilihan seseorang menjadi relawan tentunya akan disertai dengan tanggung jawab yang diembannya sebagai relawan. Dalam upaya menjalankan tanggung jawab mereka ketika melakukan penanganan bencana, relawan dapat mengalami berbagai perkembangan kondisi psikologis yang positif tersebut.

Beberapa penelitian menunjukkan bahwa ketika menjalankan tanggung jawabnya sebagai relawan, mereka dapat merasakan emosi positif. Karinda dan Arianti (2020) menyatakan bahwa setelah memberikan bantuan, relawan merasakan adanya emosi positif seperti bahagia, rasa senang, rasa syukur dan kepuasan hidup. Handian et al. (2017) juga melaporkan perasaan bahagia pada relawan ketika mereka berbagi dengan anak yang mengidap kanker. Akhtar (2017) juga mengkaji kebahagiaan relawan dalam menjalankan tugasnya dan melaporkan bahwa di antara dampak yang dialami relawan adalah menjadi lebih positif dan bersyukur atas hidupnya. Nuryanti (2020) juga melaporkan bahwa rasa bahagia adalah salah satu dampak positif yang dialami para relawan ketika menjalankan tanggung jawabnya.

Penelitian terdahulu tentang kebahagiaan pada relawan secara umum sudah pernah dilakukan seperti pada beberapa penelitin yang dibahas di atas. Namun, penelitian tentang kebahagiaan pada relawan penanganan COVID-19 masih belum banyak dilakukan. Penelitian tentang kebahagiaan yang pernah dilakukan dalam dalam konteks pandemi COVID-19 masih terbatas pada subjek secara umum. Seperti penelitian oleh O'Donnell (2020) yang menggambarkan kebahagian pada pasien transplantasi ginjal dalam masa pendemi COVID-19. Khumas dan Halima (2020) membahas tentang kebahagiaan masyarakat pada umumnya dalam menghadapi pandemi COVID-19. Penelitian Yang dan Ma (2020) serta Mei et al. (2021) juga mengukur tingkat kebahagiaan masyarakat secara umum pada masa pandemi COVID-19.

Karena itu, penelitian terkait kebahagiaan pada relawan penanganan dan pengendalian pandemi COVID-19 masih perlu dilakukan. Penelitian sebelumnya terhadap relawan penanganan COVID-19 masih belum mengkaji kondisi psikologis yang positif seperti kebahagiaan. Istiono et al. (2021) meneliti para relawan Desa 
Lawan COVID-19 dan menyimpulkan bahwa ada hubungan yang signifikan antara kematangan emosi dengan perilaku prososial pada respondennya. Namun, penelitian tersebut belum dapat mengungkap secara mendalam kondisi psikologis relawan mengingat pendekatan yang digunakan adalah kuantitatif korelasional. Penelitian lain dari Agustin et al. (2020) mengkaji dampak psikologis yang dialami oleh para relawan penanganan COVID-19 sebagai dasar untuk pemberian intervensi psikologis pada mereka. Agustin et al. (2020) melaporkan bahwa beberapa respon psikologis yang dominan dialami oleh relawan yaitu emosi negatif seperti kelelahan, ketidaknyamanan, dan ketidakberdayaan disebabkan oleh aktivitas kerja dengan intensitas tinggi, ketakutan dan kecemasan, dan kepedulian terhadap pasien dan anggota keluarganya. Kementerian Kesehatan RI (2020b) memang telah mengkategorikan relawan bencana sebagai kelompok rentan sehingga berbagai masalah fisik maupun psikologis dapat timbul dalam seluruh kegiatan yang dilakukan.

Berdasarkan kajian atas beberapa penelitian sebelumnya, dapat dilihat bahwa kondisi psikologis positif, terutama isu kebahagiaan, pada relawan yang terlibat dalam penanganan COVID-19 masih jarang dibahas. Karena itu, penelitian untuk mendalami kebahagiaan relawan penanganan pandemi COVID-19, salah satunya relawan pelacak kontak COVID-19, adalah penting untuk dilakukan.

Pelacakan kontak (contact tracing) adalah proses untuk mengidentifikasi, menilai dan mengelola orang-orang yang berkontak erat dengan kasus konfirmasi atau probable COVID-19 untuk mencegah adanyanya penularan selanjutnya. Pelacak kontak (contact tracer) adalah individu yang melakukan pelacakan kontak (contact tracing). Kontak erat adalah orang yang memiliki riwayat kontak dengan kasus konfirmasi positif COVID-19 seperti bertatap muka dalam radius 1 meter selama lebih dari 15 menit, atau bersentuhan langsung, atau merawat langsung pasien tanpa menggunakan alat pelindung diri (APD) yang sesuai, atau situasi lainnya yang berisiko (dalam satu ruangan, kantor, mode transportasi dan sejenisnya).

Kegiatan pelacakan kontak ini penting dilakukan karena kasus konfirmasi dapat menularkan virus dengan cepat. Pada kasus probable atau konfirmasi yang bergejala, kontak erat dihitung dari 2 hari sebelum kasus timbul gejala dan hingga 14 hari setelah kasus timbul gejala. Pada kasus konfirmasi yang tidak bergejala, kontak erat dihitung dari 2 hari sebelum dan 14 hari setelah tanggal pengambilan spesimen kasus konfirmasi (Kementerian Kesehatan, RI, 2020a).

Penelitian ini bertujuan untuk menggali kondisi kebahagiaan yang dimiliki oleh relawan pelacak kontak COVID-19 dalam menjalankan tugas dan tanggung jawabnya. Penelitian ini diharapkan bisa memberikan wawasan tentang kondisi mental relawan pelacak kontak COVID-19. Wawasan semacam ini dapat dijadikan bahan pertimbangan oleh masyarakat pada umumnya dan pengambil kebijakan pada khususnya dalam merespon kerja para relawan ini dengan tepat dan positif.

\section{Metode}

Pendekatan kualitatif dengan metode fenomenologi digunakan dalam penelitian ini untuk mengungkap data yang lebih mendalam. Metode fenomenologi dipilih karena memungkinkan peneliti untuk mengungkap secara rinci dan mendalam pengalaman hidup personal seseorang dan membuat deskripsi cara seseorang memberi makna terhadap dunia personal dan dunia sosialnya (Sugiarti \& Suhariadi, 2017; Hanurawan \& Suhariadi, 2019).

\section{Informan}

Informan penelitian ini adalah relawan pelacak kontak COVID-19. Lima orang berhasil direkrut untuk berpartisipasi dalam penelitian ini. Karakteristik setiap informan diuraikan secara rinci dalam Tabel 1. 
Tabel 1. Profil Informan Penelitian

\begin{tabular}{|c|c|}
\hline Informan & Karakteristik \\
\hline $\begin{array}{l}\text { Informan } \\
\text { pertama }\end{array}$ & $\begin{array}{l}\text { Jenis kelamin perempuan } \\
\text { Umur } 32 \text { Tahun } \\
\text { Relawan dari Organisasi } \\
\text { Non Pemerintah } \\
3 \text { bulan menjadi relawan } \\
\text { Pendidikan Sarjana Ilmu } \\
\text { Sosial }\end{array}$ \\
\hline $\begin{array}{l}\text { Informan } \\
\text { kedua }\end{array}$ & $\begin{array}{l}\text { Jenis kelamin laki-laki } \\
\text { Umur } 23 \text { Tahun } \\
\text { Relawan dari Organisasi } \\
\text { Non Pemerintah } \\
3 \text { bulan menjadi relawan } \\
\text { Pendidikan Sarjana Ilmu } \\
\text { Pendidikan }\end{array}$ \\
\hline $\begin{array}{l}\text { Informan } \\
\text { ketiga }\end{array}$ & $\begin{array}{l}\text { Jenis kelamin laki-laki } \\
\text { Umur } 37 \text { Tahun } \\
\text { Relawan dari Organisasi } \\
\text { Non Pemerintah } \\
3 \text { bulan menjadi relawan } \\
\text { Pendidikan Sarjana Ilmu } \\
\text { Sosial }\end{array}$ \\
\hline $\begin{array}{l}\text { Informan } \\
\text { keempat }\end{array}$ & $\begin{array}{l}\text { Jenis kelamin perempuan } \\
\text { Umur } 23 \text { Tahun } \\
\text { Relawan dari Pemerintah } \\
\text { (BNPB) } \\
2 \text { bulan menjadi relawan } \\
\text { Pendidikan Sarjana Ilmu } \\
\text { Kesehatan }\end{array}$ \\
\hline $\begin{array}{l}\text { Informan } \\
\text { kelima }\end{array}$ & $\begin{array}{l}\text { Jenis kelamin perempuan } \\
\text { Umur } 24 \text { Tahun } \\
\text { Relawan dari Pemerintah } \\
\text { (BNPB) } \\
2 \text { bulan menjadi relawan } \\
\text { Pendidikan Diploma } 3 \text { Ilmu } \\
\text { Kesehatan }\end{array}$ \\
\hline
\end{tabular}

\section{Pengumpulan Data}

Pada penelitian ini, metode wawancara menjadi teknik pengumpulan data utama. Wawancara dilakukan menggunakan media berupa telepon. Jenis wawancara yang dilakukan adalah wawancara semiterstruktur yaitu jenis wawancara dengan pedoman umum yang bersifat terbuka dan memberikan kebebasan pada subjek untuk berbicara lebih luas (Salim \& Syahrum, 2012). Pedoman umum yang digunakan memuat isu-isu dari tema yang dikaji, yaitu: 1) latar belakang atau mengapa dan tujuan menjadi relawan; 2) kepuasan pribadi terhadap yang dijalani saat ini menjadi; 3) emosi positif yang dirasakan saat menjalani aktifitas sebagai relawan; 4) dukungan sosial dalam melaksanakan aktifitas sebagai relawan; dan 5) tekanan yang dialami ketika melaksanakan aktifitas sebagai relawan. Pertanyaan dalam wawancara bisa berkembang namun dengan tetap pada isu-isu yang ada dalam tema yang dibahas. Wawancara dilakukan pada setiap subjek sebanyak satu kali dan berlangsung selama kurang lebih 45 menit untuk setiap informan. Seluruh wawancara direkam. Semua informan telah diberi informasi yang mencukupi tentang penelitian ini dan hak kerahasiaan mereka dan telah menyatakan kesediaannya untuk berpartisipasi.

\section{Analisis Data}

Data penelitian ini dianalisis menggunakan interpretative phenomenological analysis (IPA) dengan langkah-langkah meliputi (Purnamasari \& La Kahija, 2018): 1) membaca satu transkrip secara berulang; 2) pencatatan awal pada transkrip; 3) mengembangkan catatan awal menjadi tematema emergent; 4) mencari hubungan yang sama antar tema; 5) berpindah ke kasus selanjutnya; 6) mencari pola-pola yang sama antar kasus; dan 7) mendeskripsikan tema induk. Dalam penelitian ini, upaya menjaga kesahihan hasil penelitian dilakukan melalui deskipsi mendalam dan kaya pada tafsiran peneliti atas data sebagai bentuk konstruksi peneliti atas fenomena yang dikaji (Salim \& Syahrum, 2012)

\section{Hasil}

Penelitian ini berhasil mengungkap lima tema utama yaitu: 1) latar belakang dan tujuan menjadi relawan pelacak kontak COVID-19; 2) kepuasan pribadi sebagai relawan; 3) emosi positif saat menjalankan tugas sebagai relawan; 4) dukungan lingkungan sosial dalam menjalankan tugas 
relawan; dan (5) tekanan yang dialami dalam menjalankan tugas relawan dan dam- pak afektifnya. Uraian lima tema tersebut tercantum dalam Tabel 2.

Tabel. 2 Pengelompokan Tema Hasil Penelitian

\begin{tabular}{|c|c|c|}
\hline Tema Utama & Subtema & Ekstrak Wawancara \\
\hline \multirow{6}{*}{$\begin{array}{l}\text { Latar } \\
\text { belakang dan } \\
\text { tujuan } \\
\text { menjadi } \\
\text { relawan }\end{array}$} & $\begin{array}{l}\text { Pengalaman } \\
\text { berharga }\end{array}$ & $\begin{array}{l}\text { Ini menjadi hal yang luar biasa mas, pengalaman yang spesial } \\
\text { bagi saya. }\end{array}$ \\
\hline & $\begin{array}{l}\text { Panggilan } \\
\text { untuk } \\
\text { menolong }\end{array}$ & $\begin{array}{l}\text { Sebagai makhluk sosial kita nggak hidup sendiri mas, ada } \\
\text { orang lain yang menjalani kehidupan di sekitar kita, maka } \\
\text { menjadi hal yang seharusnya kita lakukan untuk menolong } \\
\text { sesama. }\end{array}$ \\
\hline & $\begin{array}{l}\text { Minat bekerja } \\
\text { dengan } \\
\text { komunitas }\end{array}$ & $\begin{array}{l}\text { Sejak kuliah saya tertarik untuk beraktifitas bersama } \\
\text { masyarakat, menjadi suatu hal yang menarik mas, gimana ya } \\
\text { menjelaskan rasanya.. pokoknya memang menjadi hal yang } \\
\text { menyenangkan lah mas bekerja dengan komunitas. }\end{array}$ \\
\hline & Proses belajar & $\begin{array}{l}\text { Banyak yang saya pelajari dalam menjalankan tugas saya, ini } \\
\text { adalah pembelajaran bagi saya. }\end{array}$ \\
\hline & $\begin{array}{l}\text { Mengambil } \\
\text { peran }\end{array}$ & $\begin{array}{l}\text { "Sangat spesial kan mas, kita menjadi bagian dalam } \\
\text { penanganan bencana yang sangat langka terjadi di dunia. }\end{array}$ \\
\hline & $\begin{array}{l}\text { Mempraktik- } \\
\text { kan ilmu }\end{array}$ & $\begin{array}{l}\text { "Wajarlah pak, saya kan pengen mempraktikkan yang saya } \\
\text { pelajari waktu kuliah." }\end{array}$ \\
\hline \multirow[b]{2}{*}{$\begin{array}{l}\text { Kepuasan } \\
\text { pribadi } \\
\text { sebagai } \\
\text { relawan }\end{array}$} & Puas & $\begin{array}{l}\text { Puas banget mas, apalagi kalau melihat kontak erat yang kita } \\
\text { pantau nurut, mau isolasi, rasanya puas banget kita mas. }\end{array}$ \\
\hline & Gembira & $\begin{array}{l}\text { Gimana kita nggak gembira mas, pas kita telepon, pasiennya } \\
\text { bilang kalau mereka sudah diperbolehkan pulang dari tempat } \\
\text { isolasi yang disediakan pemerintah, benar-benar gembira mas } \\
\text { kalau pas seperti itu, yang kita kerjakan ternyata bisa } \\
\text { menolong orang lain dan membuat mereka sembuh. }\end{array}$ \\
\hline \multirow[t]{3}{*}{$\begin{array}{l}\text { Emosi positif } \\
\text { saat } \\
\text { menjalankan } \\
\text { tugas } \\
\text { relawan }\end{array}$} & Bersyukur & $\begin{array}{l}\text { Saya ketemu dengan pasien yang } 1 \text { keluarga dimana suami, } \\
\text { istri, dan ibu dari suami positif COVID-19. Sesuai peraturan, } \\
\text { mereka harus dirujuk untuk isolasi di tempat yang disediakan } \\
\text { pemerintah. Sementara mereka punya anak yang masih berusia } \\
3 \text { tahun, anaknya berdasarkan hasil swab negatif. Mereka } \\
\text { bingung, di satu sisi mereka mau dirujuk di tempat isolasi, } \\
\text { namun di satu sisi mereka juga bingung dengan anaknya, mau } \\
\text { dititip ke mana. Untuk diajak ke tempat isolasi tidak mungkin. } \\
\text { Kadang ketika kita melihat langsung cobaan yang mereka } \\
\text { alami seperti ini, kita bersyukur mas, masih diberi kesehatan } \\
\text { sama Allah SWT, kesehatan untuk kita dan keluarga. }\end{array}$ \\
\hline & Senang & $\begin{array}{l}\text { Kalau kontak erat yang kita anjurkan untuk swab di puskesmas } \\
\text { memberi kabar hasilnya negatif, dengar mereka menyampaikan } \\
\text { dengan gembira, rasanya ya ikut senang juga. }\end{array}$ \\
\hline & Bahagia & $\begin{array}{l}\text { Ya bahagialah mas, ketika saya lakukan pemantauan pada } \\
\text { pasien COVID, lalu mereka bilang kalau hasil swab terakhir- } \\
\text { nya negatif dan boleh pulang, bahagia banget } d e h \text { dengarnya. }\end{array}$ \\
\hline
\end{tabular}




\begin{tabular}{|c|c|c|}
\hline & Kepuasan & $\begin{array}{l}\text { Pas kita ketemu dengan kontak erat yang satu keluarga itu } \\
\text { semuanya masuk dalam kategori kontak erat dan mereka mau } \\
\text { melakukan swab di puskesmas sesuai dengan yang kita } \\
\text { anjurkan .., rasanya puas banget mas, karena ... berarti kan } \\
\text { bisa sesegera mungkin terdeteksi. }\end{array}$ \\
\hline \multirow[t]{2}{*}{$\begin{array}{l}\text { Dukungan } \\
\text { lingkungan } \\
\text { sosial dalam } \\
\text { menjalankan } \\
\text { tugas } \\
\text { relawan }\end{array}$} & $\begin{array}{l}\text { Dukungan } \\
\text { keluarga dan } \\
\text { lingkungan }\end{array}$ & $\begin{array}{l}\text { Alhamdulillah saya dibesarkan dalam keluarga yang peduli } \\
\text { dengan sekitar mas, jadi ketika mereka saya kasih tahu saya } \\
\text { akan menjadi relawan pelacak kontak COVID-19, mereka } \\
\text { mendukung saya. Begitu juga dengan teman-teman saya } \\
\text { mereka mendukung apa yang saya lakukan, karena mereka } \\
\text { memahami juga kalau saya senang dalam hal melakukan } \\
\text { aktifutas seperti ini. }\end{array}$ \\
\hline & $\begin{array}{l}\text { Keluarga biasa } \\
\text { saja }\end{array}$ & $\begin{array}{l}\text { Ya biasa aja sih mas. Keluarga tidak khawatir namun juga } \\
\text { nggak peduli-peduli banget gitu, intinya ya mereka biasa-biasa } \\
\text { aja sih melihat aktifitas saya sebagai relawan. }\end{array}$ \\
\hline \multirow{6}{*}{$\begin{array}{l}\text { Tekanan } \\
\text { yang dialami } \\
\text { dalam } \\
\text { menjalankan } \\
\text { tugas } \\
\text { relawan dan } \\
\text { dampak } \\
\text { afektifnya }\end{array}$} & $\begin{array}{l}\text { Tidak ada hari } \\
\text { libur }\end{array}$ & $\begin{array}{l}\text { Bayangain aja pak, hari minggu dan hari libur nasional lainnya } \\
\text { pun kita mesti tetap melakukan pemantauan. Apalagi kalau ada } \\
\text { kontak erat yang hasil swabnya positif, pasien tersebut kan } \\
\text { harus kita beritahu dan persiapkan proses rujuk ke tempat } \\
\text { isolasi. Di awal-awal sih enjoy aja pak, namun akhir-akhir ini } \\
\text { kadang agak menjadi beban juga ketika di hari Minggu dan } \\
\text { hari libur lainnya, orang-orang bisa libur tapi kita harus tetap } \\
\text { menjalankan aktifitas. }\end{array}$ \\
\hline & $\begin{array}{l}\text { Sikap dan } \\
\text { perilaku orang } \\
\text { yang dipantau }\end{array}$ & $\begin{array}{l}\text { Yang kesel itu ketika kontak erat yang kita pantau itu nggak } \\
\text { mau kerjasama mas, misal mereka nggak mau untuk berdiam } \\
\text { diri di rumah, malah ngeyel tetap menjalankan aktifitas di luar } \\
\text { rumah. Bahkan pernah ada yang memaki-maki saya mas, } \\
\text { katanya kalau saya memantau mereka apasaya mau ngasih } \\
\text { makan anak dan istrinya, kadang kesel juga ngadepin yang } \\
\text { seperti ini. }\end{array}$ \\
\hline & $\begin{array}{l}\text { Kasus yang } \\
\text { terus } \\
\text { berdatangan }\end{array}$ & $\begin{array}{l}\text { Setiap ada hari libur yang berdekatan dengan hari Sabtu dan } \\
\text { Minggu atau orang bilang long weekend, nah ini biasanya akan } \\
\text { berdampak dengan bertambahnya kasus mas. Dan ini benar- } \\
\text { benar menguras tenaga dan pikiran kita mas. Kasusnya banyak, } \\
\text { terus kadang tempat rujukan untuk isolasi mesti antri, aduh } \\
\text { kadang nyesek juga mas ngrasainnya. }\end{array}$ \\
\hline & Jenuh & $\begin{array}{l}\text { Mesti mantau kontak erat dan pasien setiap hari, kadang } \\
\text { muncul kejenuhan juga mas di dalam hati. Ya wajar lah kadang } \\
\text { kita kan mengalami hal seperti itu . }\end{array}$ \\
\hline & Bertahan & $\begin{array}{l}\text { Ini tanggung jawab saya mas, atas pilihan yang saya ambil } \\
\text { menjadi relawan ini, pokoknya ya harus bertahan dengan } \\
\text { situasi saat ini. Biarpun kadang kita bener-bener lelah tanaga } \\
\text { dan pikiran kita, ya mesti harus bertahan. }\end{array}$ \\
\hline & $\begin{array}{l}\text { Masih } \\
\text { menikmati }\end{array}$ & $\begin{array}{l}\text { Dinikmatin aja mas, ya bagaimana kita bisa atur diri kita } \\
\text { ajalah mas. Kalau ini saya nikmati rasanya kok ya lebih enak } \\
\text { njalaninnya. Mau dikeluhkan pun percuma toh, jadi ya } \\
\text { dinikmati aja. }\end{array}$ \\
\hline
\end{tabular}




\section{Latar Belakang dan Tujuan Menjadi Relawan}

Informan pertama mengatakan bahwa dirinya terpanggil untuk ikut serta terlibat dalam penanganan dan penanggulangan COVID-19 ini karena bencana kesehatan yang tegolong pandemi adalah kejadian yang langka terjadi di dunia. Menjadi bagian dari sebuah team yang berusaha untuk menangani kejadian ini adalah pengalaman yang sangat berharga dan memiliki nilai tersendiri. Dengan ikut terlibat sebagai relawan pelacak kontak COVID-19 ini dia ingin membantu masyarakat secara umum agar pandemi ini bisa diatasi.

Informan kedua mengatakan bahwa menjadi relawan adalah seperti hobi yang melekat pada dirinya. Setiap ada bencana baik itu bencana alam atau kesehatan, dirinya selalu terpanggil untuk ikut terlibat menjadi relawan guna penanganan bencana yang terjadi. Bekerja dengan komunitas dan membantu masyarakat menjadi kepuasan tersendiri, karena pada dasarnya ketika dia menjalani aktifitas sebagai relawan dia pun sedang melakukan proses pembelajaran terhadap masyarakat itu sendiri.

Informan ketiga mengatakan bahwa dengan menjadi relawan dia berharap bisa ikut mengambil peran dalam penanganan pandemi COVID-19 ini. Pandemi ini butuh kerjasama dan peran dari seluruh elemen masyarakat sehingga pandemi ini bisa segera diatasi. Informan keempat mengatakan bahwa selama ini dia melihat korban dari pandemi COVID-19 ini semakin bertambah. Untuk itu dengan menjadi relawan pelacak kontak COVID-19 ini, dia bisa membantu pemerintah dalam melakukan penanganan pandemi ini dengan tujuan agar masyarakat bisa melaksanakan aktifitasnya secara normal lagi.

Sementara informan kelima mengatakan bahwa sebagai orang yang memiliki pendidikan kesehatan, maka saat ini adalah saat yang tepat untuk mengimplementasikan ilmu yang dimilikinya guna membantu pemerintah dan masyarakat dalam upaya menangani pandemi COVID-19 ini.

\section{Kepuasan Pribadi sebagai Relawan}

Informan pertama mengatakan adanya kepuasan yang dirasakan ketika melakukan aktifitasnya sebagai relawan pelacak kontak COVID-19, apalagi saat mendengar bila ada orang yang terkonfirmasi positif COVID-19 yang dipantaunya sudah dinyatakan sembuh. Kesembuhan dan kegembiraan dari orang yang terkena COVID-19 ini menjadikan munculnya kepuasan dalam dirinya. Informan kedua mengatakan bahwa kesempatan untuk ikut terlibat dalam penanganan COVID-19 ini merupakan hal yang istimewa dalam hidupnya. sebagai relawan pelacak kontak COVID-19 dia merasa puas dengan apa yang sudah dikerjakannya.

Informan ketiga dan keempat menyatakan bahwa dalam menjalankan aktivitasnya sebagai relawan, mereka merasa puas dengan apa yang dikerjakannya. Sedangkan informan kelima menyatakan bahwa apa yang telah dilakukannya mungkin belum seberapa dibandingkan dengan relawan-relawan lainnya, namun secara pribadi dia juga puas dengan apa yang telah dikerjakannya.

\section{Emosi Positif sebagai Relawan}

Informan pertama menyatakan bahwa ada rasa senang ketika bisa membantu dan berbagi pengetahuan dengan masyarakat, dan ikut bersyukur bila ada orang positif COVID-19 yang dipantaunya kemudian dinyatakan sembuh. Dia juga merasa adanya kepuasan dalam dirinya ketika menjalankan aktifitasnya sebagai relawan. Informan kedua menyatakan bahwa dia sangat senang dan bahagia ketika bisa ikut serta menjadi bagian dari upaya penanggulangan COVID19 ini. Dengan menjadi relawan pelacak kontak COVID-19, artinya dia telah ikut serta membantu masyarakat untuk memutus rantai penyebaran virus ini.

Informan ketiga menyatakan bahwa ada emosi positif yang dirasakannya saat dia menjalani aktifitas sebagai relawan, yaitu rasa syukur dari apa yang dialaminya secara pribadi. Sebagai relawan, kadang ia bertemu orang dengan cobaan hidup yang lebih 
berat dari cobaan hidup yang dijalaninya. Dia merasa bayak belajar dari penyintas COVID-19. Informan keempat menyatakan bahwa emosi positif yang dirasakannya adalah rasa senang dan bahagia bila mendengar orang yang positif COVID-19 yang dipantaunya sudah diperbolehkan pulang dari tempat karantina. Selain itu rasa senang juga dirasakan bila ada orang dengan kontak erat dari orang terkena COVID-19 berdasarkan hasil pemeriksaan ternyata dinyatakan negatif. Artinya, dia telah ikut serta membantu orang lain, dan ini menimbulkan kesenangan dan kebahagiaan dalam dirinya. Informan kelima menyatakan bahwa dia merasa senang dan bahagia dalam melakukan aktifitasnya sebagai relawan karena bisa ikut serta dalam membantu masyarakat dalam menghadapi pandemi COVID-19.

\section{Dukungan Lingkungan Sosial dalam Melaksanakan Tugas Relawan}

Informan pertama menyatakan bahwa keluarga dan lingkungan di mana dia bekerja sangat mendukung denga apa yang dilakukannya sebagai relawan. Hal ini tentunya membuat dia merasa lebih lepas dalam menjalankan tanggung jawabnya. Informan kedua menyatakan bahwa dukungan muncul dari keluarga dan lingkungan di mana dia saat ini beraktifitas. Ini tentunya menambah semangat baginya untuk menjalankan kegiatannya sebagai relawan. Informan ketiga menyatakan bahwa keluarganya saat ini ikut mendukung dengan pilihan dia menjadi relawan pelacak kontak COVID19, begitu juga dengan lingkungan di mana dia beraktifitas. Lingkungan ini mendukung dia dalam menjalankan tanggung jawabnya sebagai relawan.

Informan keempat mengatakan bahwa awalnya keluarga agak khawatir dengan pilihannya sebagai relawan pelacak kontak COVID-19, namun setelah berdiskusi lebih lanjut akhirnya keluarganya bisa mengerti akan pilihannya. Sementara lingkungan tempatnya beraktifitas sebagai relawan juga mendukung tugasnya. Bantuan selalu dia dapatkan ketika membutuhkan pertolongan.
Sedangkan informan keempat menyatakan bahwa keluarga bersikap biasa saja ketika dia mengatakan ikut menjadi relawan pelacak kontak COVID-19. Sementara untuk lingkungan di mana dia beraktivitas sebagai relawan, ia melaporkan bahwa mereka memberi dukungan atas apa yang dia kerjakan.

\section{Tekanan-Tekanan yang Dialami sebagai Relawan Saat Bertugas}

Informan pertama menyatakan bahwa dalam menjalankan aktifitasnya sebagai relawan pelacak kontak COVID-19, dirinya harus siap untuk melaksanakan tugas dari hari Senin sampai dengan Minggu. Tidak jarang dia harus segera menindaklanjuti kasus yang diinformasikan kepadanya di malam hari untuk segera dilakukan penanganan. Hal ini tentu menjadi tekanan pada dirinya, namun dia menyadari bahwa menjadi relawan penanganan COVID-19 memang harus selalu siap setiap saat. Sebagai relawan, saat ini dia masih menikmati apa yang dijalaninya dan berharap semoga pandemi COVID-19 ini bisa segera berlalu.

Informan kedua menyatakan bahwa kadang dia menemui orang yang dinyatakan positif COVID-19 ataupun kontak erat dari orang yang positif COVID-19 yang dipantaunya kurang mematuhi anjurannya, padahal apa yang dianjurkan olehnya tentunya sesuai dengan Pedoman Pencegahan dan Pengendalian COVID-19 yang diatur pemerintah. Bahkan kadang dijumpai sikap yang tidak baik yang ditujukan kepadanya dari Kontak Erat atau orang yang dinyatakan positif COVID-19. Terkadang dia merasa kesal juga mendapat perlakukan seperti ini. Namun dia mencoba untuk menempatkan dirinya seandainya berada pada posisi orang yang positif COVID-19 serta Kontak Eratnya, mungkin dia pun akan berperilaku seperti mereka. Sampai saat ini dia masih mampu bertahan untuk terus menjadi relawan dan berharap semoga pademi ini bisa segera teratasi dengan cepat.

Informan ketiga menyatakan bahwa te- 
kanan yang dialaminya sebagai relawan adalah jam kerja yang terus menerus melekat sepanjang waktu. Dia harus selalu siap bila ada informasi yang harus ditindaklanjuti dan ditanganinya. Tugas ini tidak mengenal hari libur. Dalam 7 hari selama seminggu harus selalu siap untuk menjalankan tanggung jawabnya sebagai pelacak kontak COVID-19. Saat ini dia mulai merasa jenuh menjalani aktivitasnya sebagai relawan.

Informan keempat menyatakan bahwa kasus konfirmasi positif yang harus segera ditindak lanjuti dari supervisornya tidak mengenal waktu, terkadang di malam hari pun dia mendapatkan kasus untuk segera dia tindak lanjuti. Seminggu penuh dia harus selalu siap dalam menindaklanjuti kasus yang diberikan kepadanya. Dia menyadari bahwa penanganan kesehatan pada orang yang dinyatakan positif COVID-19 memang harus segera dilakukan, begitu juga kontak erat dari orang yang dinyatakan positif itu harus segera ditelusuri. Namun dia juga merasakan hal ini sangat menguras tenaga dan pikirannya. Dia berharap pemerintah bisa banyak merekrut relawan pelacak kontak COVID-19 sehingga jam kerja dan hari kerja bisa diatur sedemikian rupa sehingga ada hari yang benar-benar istirahat. Karena sampai dengan saat ini tidak ada hari yang benar-benar bisa dijadikan hari libur bagi relawan. Saat ini dia masih bisa bertahan sebagai relawan, namun mulai ada kejenuhan dalam dirinya.

Informan kelima menyatakan bahwa tekanan dalam menjalani aktifitas yang dialaminya sebagai relawan tentu ada, namun dia menerima bahwa itu adalah bagian dari tanggung jawab yang telah dipilihnya. Saat ini dia menikmati dengan apa yang dilakukannya sebagai relawan pelacak kontak COVID-19

\section{Pembahasan}

Kebahagian dari para informan relawan pelacak kontak COVID-19 tergambar dari laporan mereka terkait dengan perasaan positif yang dialaminya ketika melaksana- kan tugas. Perasaan positif yang dominan pada para informan adalah rasa senang dan bahagia bisa menebar kebaikan dengan menolong sesama. Rasa puas diri yang diperoleh dengan menolong orang lain yang dialami para infroman ini sekaligus meneguhkan motivasi mereka untuk menjadi relawan. Temuan ini selaras dengan hasil penelitian Laila dan Asmarany (2015) yang melaporkan motivasi utama subjeknya untuk menjadi relawan adalah karena keinginan untuk menolong orang yang sedang membutuhkan. Tindakan menolong ini dapat mendatangkan kepuasan pada diri pada para relawan.

Kegembiraan para informan relawan pelacak kontak COVID-19 ini juga muncul karena mereka memandang bahwa kehadiran mereka sebagai relawan telah membuat orang lain merasa terbantu. Munculnya emosi positif seperti rasa senang, bahagia, puas, dan bersyukur pada para informan tidak bisa dilepaskan dari adanya interaksi mereka sebagai relawan dengan masyarakat yang dibantunya. Hal ini juga sesuai dengan hasil penelitian Karinda dan Arianti (2020) yang melaporkan bahwa kepuasan hidup dirasakan oleh relawan karena terjalinnya interaksi secara langsung dengan masyarakat yang dibantu (Karinda \& Arianti, 2020).

Kebahagiaan para informan penelitian ini juga tergambar dari laporan mereka tentang dukungan yang diperoleh dari keluarga dan lingkungan tempat mereka menjalankan tugasnya sebagai relawan pelacak kontak COVID-19. Hal ini sesuai dengan penelitian Soraya dan Husna (2019) yang menyatakan bahwa sumber eksternal seperti dukungan lingkungan sosial dari keluarga dan teman para relawan dapat memperkuat motivasi mereka sebagai relawan.

Dalam penelitian ini juga ditemukan adanya tekanan yang dialami oleh informan penelitian dalam menjalankan aktiftasnya sebagai relawan pelacak kontak COVID-19 antara lain: tidak adanya hari ibur secara penuh, kasus yang terus bertambah dan harus segera ditindak lanjuti, serta respon negatif dari orang yang sedang dipantaunya. 
Tekanan-tekanan ini berdampak negatif pada diri informan seperti rasa jenuh, kesal, kelelahan dan pengalaman negatif lainnya. Namun, hampir semua informan melaporkan bahwa mereka dapat mengatasi afeksi negatif tersebut dalam tingkat yang berbeda-beda. Sebagian besar subjek merasa siap melanjutkan tugasnya sebagai relawan, sedangkan sebagian kecil melaporkan sudah mulai merasa jenuh.

Perbedaan dalam mengatasi tekanan ini terjadi karena setiap individu mempunyai ketahanan dan kemampuan tersendiri dalam menghadapi suatu masalah (Sugiarti et al., 2020). Melina et al. (2012) melaporkan bahwa stresor yang umum dialami oleh para relawan adalah adanya bahaya mengancam (seperti penyakit, gempa susulan, dan jenis bahaya lainnya) yang menimbulkan perasaan takut, berkurang atau hilangnya privasi, cemas karena jauh dari keluarga, tuntutan fisik yang berat, kondisi tugas yang tidak menyenangkan, beban kerja yang berlebihan dalam jangka waktu lama, konflik interpersonal yang mungkin timbul di antara relawan, serta teringat akan tragedi, kisah, atau cerita-cerita traumatis disebabkan oleh bencana.

Beberapa stresor tersebut ada yang dialami para infroman penelitian ini. Namun, perasaan positif yang diperoleh selama menjadi relawan telah membantu mereka mengatasi tekanan-tekanan tersebut dan berhasil bertahan dan melanjutkan tugas sebagai relawan pelacak kontak COVID-19.

\section{Simpulan}

Berdasarkan hasil penelitian, dapat diambil kesimpulan bahwa kebahagiaan relawan pelacak kontak COVID-19 tergambar dari rasa senang, puas, gembira, dan bahagia karena merasa bermanfaat bagi orang lain. Respon positif dari orang yang dibantu dan hasil positif dari bantuan yang diberikan menjadi sumber utama kebahagiaan tersebut. Beberapa tekanan dialami selama menjalankan tugas sebagai relawan dan menghasilkan afek negatif. Namun, dukungan sosial yang diperoleh dari keluarga dan lingkungan kerja telah memperkuat motivasi mereka untuk menjadi relawan. Bersama dengan motivasi awal mereka untuk menjadi relawan pelacak kontak COVID-19, emosi positif yang dihasilkan dari aktivitas mereka selama menjalani tugas relawan telah mendorong para informan penelitian ini untuk bertahan dalam tugas kerelawanannya.

\section{Saran}

Secara teoritis, dalam penelitian ini belum tergali lebih dalam tentang motivasi menjadi relawan pelacak kontak COVID19. Penelitian ini hanya memotret gambaran umum dari latar belakang sebagai relawan hingga kebahagiaan sebagai emosi positif dominan yang diperoleh selama menjalani tugas relawan. Selanjutnya penelitian ini belum menggali bagaimana para subjek mengatasi tekanan-tekanan yang dialami selama menjalankan tugas kerelawanan. Topik ini bisa diangkat dan didalami oleh penelitian selanjutnya.

Secara praktis, hasil penelitian ini dapat dijadikan wawasan bagi relawan atau calon relawan dalam mengemban tanggung jawabnya dan mengantisipasi beban tugas yang akan dialaminya. Hal ini penting agar nantinya relawan yang bekerja di lapangan dapat mempersiapkan diri dengan baik secara fisik maupun mental. Selain itu, hasil penelitian ini juga bisa dijadikan bahan masukan bagi pemerintah atau organisasi non-pemerintah yang terlibat dalam penanganan pandemi COVID-19 ini agar dapat membuat sistem kerja dan insentif yang sepadan terhadap petugas lapangan. 


\section{Daftar Pustaka}

Agustin, I. M., Nurlaila, N. \& Yuda. H. T. (2020). Efektifitas Terapi Individu Pada Kondisi Psikologis, Relawan Bencana Covid-19. Proceeding of the 12th University Research Colloquium 2020: Bidang MIPA dan Kesehatan. http://repository.urecol.org/index.php/ proceeding/article/view/1157

Akhtar, H. (2017). Psychological WellBeing of Volunteer Teacher Trainers In The Remote Area In Indonesia. IJASOS-International E-Journal of Advances in Social Sciences, 3(9), 840849. https://doi.org/10.18769/ijasos.366855

Arumwardhani, A. (2011). Psikologi Kesehatan (Buku I) . Galangpress.

Badan Pusat Statistik. (2020) Pertumbuhan Ekonomi Indonesia Triwulan IV-2020, Berita Resmi Statistik. https://www.bps.go.id/website/materi_ ind/materiBrsInd-

20210205095341.pdf

Diyantara, D. (2016, 31 Maret). Pengertian Relawan dan Ketentuannnya. http://aksisolidaritas.blogspot.com/201 6/03/pengertian-relawan-danketentuannnya.html

Ellryz, R. (2017). Perlindungan Relawan Kemanusiaan dalam Konflik Bersenjata Menurut Hukum Humaniter. Lex et Societatis, 5(2), 3946.https://doi.org/10.35795/les.v5i2.15 233

Fitriani, N. R. \& Setyawan, I (2018). Hidup Hanya Sekali, Hiduplah Yang Berarti: Sebuah Studi Kualitatif Pengalaman Tobat pada Mantan Preman Relawan Lembaga Sosial. Jurnal Empati, 7(2), 672-681.

https://ejournal3.undip.ac.id/index.php /empati/article/view/20145/19004

Melina, G. G., Grashinta, A., \& Vinaya, V. (2012). Resiliensi dan Altruisme Pada
Relawan Bencana Alam. Jurnal Psikologi Ulayat, 1(1), 17-24. https://doi.org/10.24854/jpu12012-7

Handian, F. I., Fitria, Y., \& Falah, M. R. (2017). Mendukung Kepatuhan Pengobatan dengan Berbagi Kebahagiaan dan Menjadi Sahabat: Studi Kasus di Komunitas Sahabat Anak Kanker Malang, Indonesia. The Indonesian Journal of Health Science, $8(2)$, 165-170. https://doi.org/10.32528/the.v8i2.870

Hanurawan, F. \& Suhariadi, F. (2019). Filsafat Ilmu Psikologi. PT Remaja Roesdakarya.

Harahap, S. R. (2020). Proses Interaksi Sosial Di Tengah Pandemi Virus Covid 19. AL-HIKMAH, 11(1), 45-53. https://doi.org/10.32505/hikmah.v11i1 .1837

Hilman, B. (2018, Mei) Pengertian Kebahagiaan (Happiness) dan AspekAspek Happiness Menurut Para Ahli https://www.universitaspsikologi.com/ 2018/05/pengertian-dan-aspekkebahagiaan-happiness.html

Istiono, A., Suroso, \& Pratitis, N. T. (2021). Kematangan Emosi dan Perilaku Prososial Pada Relawan Desa Lawan Covid 19 Ditinjau Dari Jenis Kelamin. Seminar Nasional Konsorsium Untag Indonesia Ke-2 Tahun 2020. http://repository.untag-sby.ac.id/4089/

Karinda, J. J., \& Arianti, R . (2020). Potret Kebahagiaan Relawan Studi Kasus Relawan Satya Wacana Peduli di Lombok. Humanitas, 4(1), $101-116$. https://doi.org/10.28932/humanitas.v4i 1.2397

Kementerian Kesehatan RI. (2020a). Panduan Singkat Pelacakan Kontak (Contact Tracing) untuk Kasus COVID-19. https://covid19.kemkes.go.id/documen 
t/buku-saku-pelacakan-kontak-kasuscovid-19-edisi-revisi-i/view

Kementerian Kesehatan RI. (2020b). Pedoman Pencegahan dan Pengendalian Coronavirus Diseases (Covid-19).

https://covid19.kemkes.go.id/protokolcovid-19/kmk-no-hk-01-07-menkes413-2020-ttg-pedoman-pencegahandan-pengendalian-covid-19.

Khumas, A. \& Halima, A. (2020). Descriptive Study of Happiness and Meaningfulness in Facing the Covid-19 Pandemic, International Conference on Science and Advanced Technology (ICSAT).

https://ojs.unm.ac.id/icsat/article/view/ 17741

Laila, K. N. \& Asmarany, A. I. (2015). Altruisme Pada Relawan Perempuan Yang Mengajar Anak Berkebutuhan Khusus di Yayasan Anak Jalanan Bina Insani. Jurnal Psikologi, 8(1), 1-7. https://ejournal.gunadarma.ac.id/index. php/psiko/article/view/1284

Maharani, D. (2015). Tingkat Kebahagiaan (Happiness) Pada Mahasiswa Fakultas Pendidikan Universitas Negeri Yogyakarta. Jurnal Riset Mahasiswa Bimbingan dan Konseling, 4(6), 1-12. http://journal.student.uny.ac.id/ojs/ind ex.php/fipbk/article/view/186/167

Mei, N., Sivaguru, \& Chong. (2021). Social Support, Resilience, and Happiness in Response to COVID-19. Journal of Cognitive Sciences and Human Development. $\quad 7(1), \quad$ 134-144. https://doi.org/10.33736/jcshd.2882.20 21

Melina, G. G., Grashinta, A. \& Vinaya, (2012). Resiliensi Dan Altruisme Pada Relawan Bencana Alam. Jurnal Psikologi Ulayat, 1(1), 17-24, https://doi.org/10.24854/jpu1

Muslim, M. (2020). Manajemen Stress Pada Masa Pandemi Covid-19. ESENSI: Jurnal Manajemen Bisnis,
23(2), 192-201. https://ibn.ejournal.id/index.php/ESENSI/article/vi ew/205

Nugrahani, A. W. (2021, 5 Juni). Update Corona Global 5 Juni 2021: Total Kasus Aktif di Seluruh Dunia Capai 13,3 Juta, India 1,5 Juta. https://www.tribunnews.com/corona/2 021/06/05/update-corona-global-5juni-2021-total-kasus-aktif-di-seluruhdunia-capai-133-juta-india-15-juta.

Nuryanti (2021, 4 Mei). UPDATE Kasus Corona Indonesia 4 Mei 2021: Tambah 4.369 Positif, 5.658 Sembuh, dan 188 Meninggal.https://www.tribunnews.co $\mathrm{m} /$ corona/2021/05/04/update-kasuscorona-indonesia-4-mei-2021-tambah4369-positif-5658-sembuh-dan-188meninggal.

Nuryanti, S. (2020). Empathy And Happiness Of Disaster Volunteers. Interaktif Jurnal Ilmu-Ilmu Sosial, 12(2), 82-93. https://interaktif.ub.ac.id/index.php/int eraktif/article/view/244

O'Donnell, A. (2020). Life satisfaction and happiness in patients shielding from the COVID-19 global pandemic: A randomised controlled study of the 'mood as information' theory. Plos One, 15(12), 1-10. https://doi.org/10.1371/journal.pone.0 243278

Pakpahan, A. K. (2020). COVID-19 dan Implikasi Bagi Usaha Mikro, Kecil, dan Menengah. Jurnal Ilmiah Hubungan Internasional, Edisi Khusus, 59-64.

https://doi.org/10.26593/jihi.v0i0.3870 $.59-64$

Purnamasari, A. P., \& La Kahija, Y. F. (2018). Mengajar Sembari Belajar: Sebuah Interpretative Phenomenological Analysis tentang Pengalaman Pengajar Muda Gerakan Indonesia Mengajar. Jurnal Empati, 7(4),

345-358. 
https://ejournal3.undip.ac.id/index.php /empati/article/download/23486/21432

Raharjo, S. T. (2002). Manajemen Relawan Pada Organisasi Pelayanan Sosial. Jurnal Sosiohumaniora, 4(3),150-173 https://doi.org/10.24198/sosiohumanio ra.v4i3.5299

Rizkiawati, R., Wibhawa, B., Budiarti, M. S., \& Raharjo, S. T. (2015). Pentingnya Buku Panduan Bagi Volunteer Pada Organisasi Sosial (Studi Kasus Pada Lembaga Rehabilitasi ODHA dan Konsumen NAPZA Rumah Cemara). Social Work Jurnal, 7(2), 53-61. https://doi.org/10.24198/share.v7i2.15 723

Salim \& Syahrum, (2012). Metodologi Penelitian Kualitatif: Konsep dan Aplikasi dalam Ilmu Sosial, Keagamaan dan Pendidikan (Edisi kelima). Citapustaka Media.

Satrianingrum, A. P \& Prasetyo, I. (2021). Persepsi Guru Dampak Pandemi Covid-19 terhadap Pelaksanaan Pembelajaran Daring di PAUD. Jurnal Obsesi: Jurnal Pendidikan Anak Usia Dini, 5(1), 633-640. https://doi.org/10.31004/obsesi.v5i1.5 74

Septania, S. \& Khairani (2016). Muda, Berani dan Tanpa Pamrih: Karakter Grit pada Perilaku Ta'awun Relawan
Muda Muhammadiyah. Jurnal Sains Psikologi, $\quad$ 9(1), 15-25. http://journal2.um.ac.id/index.php/JSP si/article/view/11399

Soraya, Y., \& Husna, J. (2019). Motivasi Relawan Melalui Media Sosial Facebook pada Gerakan Donasi Motor Pustaka di Desa Pematang Pasir Kecamatan Ketapang Kabupaten Lampung Selatan. Jurnal Perpustakaan, 8(2) 256-266. https://ejournal3.undip.ac.id/index.php /jip/article/download/26814/23664

Sugiarti, R., \& Suhariadi, F. (2017). Picture of Gifted Intelligent Student's Social Competence. International Journal of Humanities, Arts and Social Sciences. $3(1)$, 20-26. https://dx.doi.org/10.20469/ijhss.3.200 04-1

Tuwu, D. (2020). Kebijakan Pemerintah Dalam Penanganan Pandemi Covid-19. Journal Publicuho, 3(2), 267-278. http://dx.doi.org/10.35817/jpu.v3i2.12 535

Yang, H. \& Ma, J. (2020). How an Epidemic Outbreak Impacts Happiness: Factors that Worsen (vs. Protect) Emotional Well-being during the Coronavirus Pandemic. Psychiatry Research, 289, 1-5, https://doi.org/10.1016/j.psychres.202 0.113045 